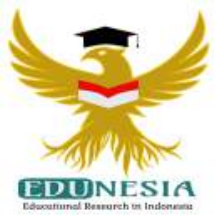

\title{
Kemampuan Menulis Puisi Bebas Menggunakan Media Gambar Pada Siswa SMPK Santo Aloysius
}

\author{
Hawiah Djumadin'; Rosa Dalima Bunga²; Maria Magdalena Rini ${ }^{3}$ \\ 1,2,3Pendidikan Bahasa dan Sastra Indonesia, Universitas Flores, Indonesia. \\ ${ }^{1}$ Corresponding Email: hawiahdjumadin99@gmail.com,Phone Number : 0822 xxxx xxxx
}

Article History:

Received: July 17, 2020

Revised: Agust 10, 2020

Accepted: Sept 14, 2020

Published: Nov 01, 2020

Keywords:

ability to write poetry, picture media.

Kata Kunci:

kemampuan menulis puisi, media gambar.

How to cite:

Djumadin, H., Bunga, R.D., \& Rini, M.M. (2020).

Kemampuan Menulis Puisi Bebas Menggunakan Media Gambar Pada Siswa SMPK Santo Aloysius. Edunesia : Jurnal Ilmiah Pendidikan, 1 (3): 54-62

This is an open access article under the $C C-B Y-N C-N D$ license
Abstract: This study aims to determine the ability to write free poetry using picture media in VII grade students of St. Aloysius Lengko Middle School, Golo Wangkung Village, Sambi Rampas District, East Manggarai Regency. The formulation of the problem in this research is how is the ability to write free poetry using picture media in VII grade students of St. Aloysius Lengko Middle School, Golo Wangkung Village, Sambi Rampas District, East Manggarai Regency? This type of research is quantitative descriptive. The sample in this study amounted to 40 students. Data collection techniques in the form of tests and documentation. The instrument used was a test sheet. The theory used is the theory of writing poetry, theory of learning strategies and learning evaluation theory. The results of the study of the ability to write poetry by using media images in students of the St. Aloysius Lengko Middle School VII class as a whole are classified as good with an average achievement of $77.47 \%$. Completed students numbered 31 people with a percentage of $77.5 \%$. While students who did not complete a total of 9 people with $22.5 \%$ presentse.

Abstrak: Penelitian ini bertujuan untuk mengetahui kemampuan menulis puisi bebas menggunakan media gambar pada Siswa kelas VII SMPK Santo Aloysius Lengko Ajang Kelurahan Golo Wangkung, Kecamatan Sambi Rampas, Kabupaten Manggarai Timur. Rumusan masalah dalam penelitian ini adalah bagaimanakah kemampuan menulis puisi bebas menggunakan media gambar pada Siswa kelas VII SMPK Santo Aloysius Lengko Ajang Kelurahan Golo Wangkung, Kecamatan Sambi Rampas, Kabupaten Manggarai Timur? Jenis penelitian ini adalah deskriptif kuantitatif. Sampel dalam penelitian ini berjumlah 40 orang siswa. Teknik pengumpulan data berupa tes dan dokumentasi. Instrument yang digunakan adalah lembar tes. Teori yang digunakan adalah teori menulis puisi, teori startegi belajar mengajar dan teori evaluasi pembelajaran. Hasil penelitian kemampuan menulis puisi dengan menggunakan media gambar pada siswa SMPK Santo Aloysius Lengko Ajang kelas VII secara keseluruhan tergolong baik dengan rata-rata pencapaian $77,47 \%$. Siswa yang tuntas berjumlah 31 orang dengan presentase $77,5 \%$. Sedangkan siswa yang tidak tuntas bejumlah 9 orang dengan presentse $22,5 \%$. 


\section{A. Pendahuluan}

Dewasa ini, pembelajaran bahasa ditujukan hanya sebatas pada keterampilan siswa menggunakan bahasa sesuai dengan konteksnya atau bersifat pragmatis. Sesungguhnya, bahasa memiliki peran sentral dalam perkembangan intelektual, sosial, dan emosional peserta didik, karena dapat menunjang keberhasilan dalam mempelajari semua bidang studi. Oleh karena itu, pembelajaran bahasa diharapkan dapat membantu peserta didik dalam mengenal dirinya, budayanya, dan budaya orang lain, mengemukakan gagasan dan perasaan, berpatisipasi dalam masyarakat, dan menemukan serta menggunakan kemampuan analitis dan imaginatif yang ada di dalam dirinya (Puskur, 2006).

Menulis merupakan salah satu keterampilan berbahasa yang sangat dibutuhkan, terutama dalam mengungakapkan ide, pikiran dan perasaan melalui sebuah tulisan atau karangan, baik karangan fiksi maupun non fiksi.Bahkan dalam kehidupan manusia hampir tidak luput dari kegiatan tulis menulis. Keterampilan menulis dipergunakan untuk berkomunikasi secara tidak langsung, tidak secara tatap muka dengan orang lain. Dalam pelajaran bahasa Indonesia, menulis merupakan salah satu keterampilan bahasa yang harus dilatih. Sebab menulis merupakan mengolah pikir, mengasah rasa, dan mengkomunikasikan hasil pmikiran dan pengasahan dalam bentuk tulisan atau karangan. Dalam penelitian ini, penelitin fokus pada menulis puisi bebas. Wissang (2014) mengemukakan menulis dalam dunia sastra khususnya puisi selalu berkaitan dengan kemampuan mengolah daya, daya kreativitas dalam diri seseorang.Kreativitas yang lahir berdasarkan pengalaman, penghayatan serta nilai-nilai kehidupan. Dalam penulisan puisi, pengalaman juga diperoleh dari berbagai peristiwa, kejadian, atau objek tertentu dalam kehidupan.

Puisi sering menampilkan kehidupan manusia sebagai "makhluk sosial" dalam hubungan dengan sesamanya. Dari pemahaman ini akan lahir kreativitas. Berkaitan dengan mengolah daya imajinasi, kemampuan membangun ide dan mengembangkannya menjadi karya kreatif dalam bentuk tulisan. Menulis dalam kaitannya dengan menulis puisi yakni mengelolah daya kreativitas berarti menuangkan pikirann atau perasaan melalui tulisan yang mengandung daya sugestif bagi pembaca. (Uer, 2013).

Adapun yang menjadi objek penelitian ini adalah siswa kelas VII SMPK Santo Aloisius Lengko Ajang yang mana dalam proses kegiatan pembelajaran puisi selama ini tidak menggunakan media apapun, disini guru menugaskan para siswa untuk menulis puisi sesuai dengan keadaan saat itu, tanpa memperhatikan keadaan siswa pada saat proses pembelajaran berlangsung, apabila siswa dalam keadaan kurang baik, maka daya imajinasi yang dihasilkan tidak sempurna. Pembelajaran puisi yang diterapkan selama ini pada siswa kelas VII SMPK Santo Aloisius Lengko Ajang belum mencapai ketuntasan maksimal.

Melihat kenyataan tersebut peneliti merasa bahwa siswa membutuhkan media yang dapat membangkitkan daya imajinasi sehingga siswa mempunyai beberapa diksi untuk menulis. Maka peneliti memilih dalam proses pembelajaran puisi pada siswa kelas VII SMPK Santo Aloisius Lengko Ajang menggunakan media gambar pada saat proses pembelajaran tentang menulis puisi. Penggunaan media gambar pada penulisan puisi sekiranya dapat memberi rangsangan kepada siswa untuk menulis puisi.

Ada beberapa konsep atau definisi media pendidikan atau media pembelajaran. Rossi dan Breidle (dalam Sanjaya 2006) mengemukakan bahwa media pembelajaran adalah seluruh alat dan bahan yang dapat dipakai untuk mencapai tujuan pendidikan 
seperti radio, televise, buku, Koran, majalah, dan sebagainya. Namun demikian, media bukan hanya alat atau bahan saja, akan tetapi hal-hal lain yang memungkinkan siswa dapat memperoleh pengetahuan. Menurut Hanafiah \& Suhana (2010) media pembelajaran merupakan segala bentuk perangsang dan alat yang disediakan guru untuk mendorang siswa belajar secara cepat, tepat, mudah, benar dan tidak terjadinya verbalisme. Selain pendapat tersebut, Prihatin (2008) menerangkan bahwa media pembelajaran adalah media yang dapat digunakan untuk membantu siswa di dalam memahami dan memperoleh informasi yang dapat didengar ataupun dilihat oleh panca indera sehingga pembelajaran dapat berhasil guna dan berdaya guna.

Berdasarkan uraian latar belakang tersebut, maka peneliti tertarik untuk melakukan penelitian dengan judul "Kemampuan Menulis Puisi Bebas Menggunakan Media Gambar pada Siswa Kelas VII SMPK Santo Aloysius Lengko Ajang Kelurahan Golo Wangkung, Kecamatan Sambi Rampas, Kabupaten Manggarai Timur". Tujuan penelitian ini adalah untuk mengetahui kemampuan siswa dalam menulis puisi bebas menggunakan media gambar pada Siswa Kelas VII SMPK Santo Aloysius Lengko Ajang Kelurahan Golo Wangkung, Kecamatan Sambi Rampas, Kabupaten Manggarai Timur. Manfaat yang didapat dari penelitian ini adalah salah satu sumber belajar atau pengembangan teori atau ilmu pengetahuan tentang pengaruh media gambar terhadap keterampilan menulis khususnya menulis puisi.

\section{B. Metode}

Metode yang digunakan dalam penelitian ini adalah metode kuantitatif karena berkaitan dengan data yang berupa angka, tabel dan bagan. Metode kuantitatif adalah sebagai metode penelitian yang berlandaskan pada filsafat positivism, digunakan untuk meneliti pada populasi atau sampel tertentu, pengumpulan data menggunakan instrument penelitian (Sugiyono, 2017). Jenis penelitiannya adalah deskriptif kuantitatif. Menurut Burhan (2005) Penelitian kuantitatif deskriptif digunakan untuk menggambarkan, menjelaskan, atau meringkaskan berbagai kondisi, situasi, fenomena, atau berbagai variabel penelitian menurut kejadian sebagaimana adanya yang dapat dipotret, diwawancara, diobservasi, serta yang dapat diungkapkan melalui bahan-bahan dokumenter.

Populasi dalam penelitian ini adalah seluruh siswa/siswi kelas VII SMPK Santo Aloysius Lengko Ajang Kelurahan Golo Wangkung, Kecamatan Sambi Rampas, Kabupaten Manggarai Timur berjumlah 40 orang. Berhubung populasi berjumlah 40 orang siswa yang tergolong sedikit maka semua siswa dijadikan sampel dalam penelitian ini.

Instrument/Teknik pengumpulan data yang digunakan dalam penelitian ini yakni, 1) Teknik tes, menurut Abidin (2015) tes adalah suatu pertanyaan atau tugas yang direncanakan untuk memperoleh informasi tentang atribut pendidikan tertentu dan setiap butir pertanyaan atau tugas tersebut atau jawaban atau ketentuan yang dianggap benar dan apabila tidak memenuhi ketentuan maka jawaban dianggap salah. Dalam penelitian ini soal yang digunakan berupa uraian. Teknik ini dilakukan untuk mengukur dan mendapatkan data atau gambaran tentang sejauh mana kemampuan menulis puisi bebas siswa kelas VII SMPK Santo Aloysius Lengko Ajang dengan menggunakan teknik tes. 2). Teknik dokumentasi, menurut Ridwan dalam Iskandar dan Narsim (2015) bahwa "dokumentasi ditujukan untuk memperoleh data langsung dari tempat penelitian, meliputi buku-buku relevan, peraturan-peraturan, laporan kegiatan, foto-foto, film dokumenter, dan data yang relevan dengan penelitian". Teknik dokumetasi dalam 
penelitian ini peneliti gunakan dengan tujuan yaitu untuk memperoleh daftar nilai siswa sebelumnya. Nilai tersebut dijadikan sebagai acuan dalam membentuk kelompok siswa yang heterogen.

Tercapainya tujuan penelitian tergantung pada kejelasan dan ketepatan dalam memilih metode dan teknik analisis data. Hal ini mengingatkan bahwa sasaran peneliti berupa pemahaman melalui pemanfaatan media gambar untuk mengetahui kemampuan siswa kelas VII SMPK Santo Aloysius Lengko Ajang dalam menulis puisi bebas menggunakan media gambar. Analisis data dilakukan secara induktif yang dikaji melalui proses yang berlangsung dari fakta.

Tabel 1.

Aspek penilaian kemampuan menulis puisi.

\begin{tabular}{ccc}
\hline No. & Aspek yang dinilai & Skor \\
\hline 1. & Tema & 20 \\
\hline 2. & Judul & 15 \\
\hline 3. & Amanat & 10 \\
\hline 4. & Diksi & 30 \\
\hline 5. & Rima & 10 \\
\hline 6. & Larik & 15 \\
\hline & Jumlah & $\mathbf{1 0 0}$ \\
\hline
\end{tabular}

Tabel 2.

Kriteria penilaian

\begin{tabular}{ccc}
\hline No. & Nilai & Kategori \\
\hline 1. & Sangat baik & $90-100$ \\
\hline 2. & Baik & $80-89$ \\
\hline 3. & Cukup & $70-79$ \\
\hline 4. & Kurang & $60-69$
\end{tabular}

Adapun langkah-langkah dalam proses pembelajaran pada penelitian ini sebagai berikut:

1) Tahap Pertama responden.

Peneliti menghimpun populasi siswa kelas VII sebanyak 40 orang sebagai 2) Tahap Kedua

Peneliti menyebarkan LKS sebagai format tes kemampuan menulis puisi bebas yang telah disediakan kepada 40 orang responden dalam mencermati hal-hal yang berkaitan dengan tahap-tahap penulisan puisi bebas yang berkaitan dengan keindahan alam.

3) Tahap Ketiga 
Siswa melakukan kegiatan menulis puisi tentang keindahan alam melalui tahaptahap sebagai berikut.

a. Mengamati objek (gambar yang telah disediakan)

b. Menulis hasil pengamatan berdasarkan data rincian yang telah disiapkan

c. Menentukan tema dan judul puisi.

d. Menulis puisi dengan memperhatikan diksi rima, dan amanat yang tepat.

4) Tahap Keempat

Siswa membaca hasil tulisan untuk mendapat masukan dari teman-teman.

5) Tahap Kelima

Peneliti mengumpulkan kembali pekerjaan responden untuk memberikan penilaian berdasarkan kriteria yang ditentukan.

6) Tahap Keenam

Pemeriksaan hasil kerja responden untuk memberikan penelitian untuk memberikan penelitian berdasarkan kriteria yang ditentukan.

7) Tahap Ketujuh

Pada tahap yang terakhir peneliti merumuskan hasil kerja responden tentang kemampuan siswa dalam menulis puisi tentang keindahan alam dengan menggunakan metode tes.

Berikut ini peneliti akan menganalisis hasil kerja siswa melalui pemerolehan nilai. Teknik yang digunakan adalah teknik induktif kuantitatif sebagai berikut:

1) Mengumpulkan semua puisi yang ditulis siswa

2) Setelah semua puisi dikumpulkan peneliti memeriksa puisi siswa satu persatu dan memberi skor sesuai dengan kemampuan siswa.

3) Setelah diberi skor peneliti menganalisis sesuai dengan teori yang digunakan.

Data yang dianalisis dengan teknik statistik menggunakan rumus Ridwan dan akdon (2010) yaitu dengan mencari :

mean $(\bar{X})=\sum \frac{x i}{n}$

Keterangan :

$\bar{X}=$ mean

$\sum x i=j u m l a h$ nilai

n=banyaknya data

Cara menganalisis data yaitu menulis siswa yang mampu dibagi jumlah responden dikali 100.

1) Untuk menentukan persentase keberhasilan siswa

Jumlah siswa yang mampu $\times 100$

Jumlah responden

2) Untuk mengetahui persentase kegagalan siswa

Jumlah siswa yang gagal $\times 100$

Jumlah responden

Dari data kemampuan siswa secara individu dapat terlihat berdasarkan isi tabel berikut : 
Tabel 3.

Kriteria Tingkat Keberhasilan Siswa Dalam \%

\begin{tabular}{ccc}
\hline No. & Arti & Tingkat keberhasilan \% \\
\hline 1. & Sangat baik & $90-100$ \\
\hline 2. & Baik & $80-89$ \\
\hline 3. & Cukup & $70-79$ \\
\hline 4. & Kurang & $60-69$ \\
\hline
\end{tabular}

Tabel 4.

Hasil Kerja Siswa

\begin{tabular}{|c|c|c|c|c|c|c|c|c|c|c|}
\hline \multirow[b]{2}{*}{$\stackrel{\circ}{z}$} & \multirow{2}{*}{ 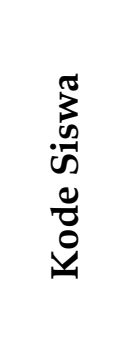 } & \multicolumn{6}{|c|}{ Aspek Penilaian } & \multirow{2}{*}{$\frac{\pi}{\bar{z}}$} & \multirow{2}{*}{ 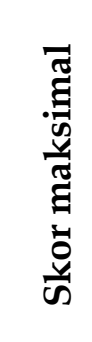 } & \multirow{2}{*}{ 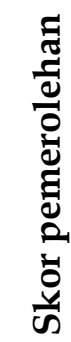 } \\
\hline & & 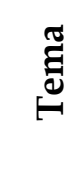 & ב & 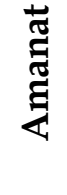 & $\begin{array}{l}\vec{D} \\
\ddot{\vec{n}}\end{array}$ & $\underset{\Xi}{\Xi}$ & 氖 & & & \\
\hline 1. & $\mathrm{AC}$ & 20 & 12 & 8 & 25 & 7 & 8 & 80 & 100 & 80 \\
\hline 2. & AS & 20 & 10 & 7 & 20 & 7 & 11 & 75 & 100 & 75 \\
\hline 3. & BSS & 20 & 15 & 7 & 20 & 8 & 10 & 80 & 100 & 80 \\
\hline 4. & $\mathrm{CON}$ & 20 & 13 & 7 & 20 & 8 & 13 & 81 & 100 & 81 \\
\hline 5. & DF & 20 & 10 & 5 & 23 & 7 & 10 & 75 & 100 & 75 \\
\hline 6 & EAJ & 20 & 11 & 6 & 20 & 8 & 11 & 76 & 100 & 76 \\
\hline 7. & FS & 20 & 11 & 6 & 20 & 8 & 11 & 76 & 100 & 76 \\
\hline 8. & FA & 20 & 13 & 7 & 20 & 8 & 13 & 81 & 100 & 81 \\
\hline 9. & GS & 20 & 13 & 8 & 19 & 8 & 12 & 80 & 100 & 80 \\
\hline 10. & HS & 20 & 15 & 6 & 25 & 9 & 6 & 81 & 100 & 81 \\
\hline 11. & IW & 20 & 12 & 8 & 23 & 8 & 9 & 80 & 100 & 80 \\
\hline 12. & JRD & 20 & 12 & 8 & 23 & 9 & 8 & 80 & 100 & 80 \\
\hline 13. & KA & 20 & 14 & 7 & 17 & 8 & 7 & 80 & 100 & 80 \\
\hline 14. & KHS & 20 & 9 & 8 & 18 & 7 & 8 & 70 & 100 & 70 \\
\hline 15. & $\begin{array}{c}\text { KAN } \\
\mathrm{M}\end{array}$ & 20 & 15 & 9 & 24 & 8 & 15 & 81 & 100 & 81 \\
\hline 16. & $\mathrm{KP}$ & 20 & 13 & 7 & 24 & 8 & 8 & 80 & 100 & 80 \\
\hline 17. & $\mathrm{KF}$ & 20 & 10 & 8 & 22 & 8 & 12 & 80 & 100 & 80 \\
\hline 18. & LAM & 20 & 10 & 8 & 22 & 7 & 13 & 80 & 100 & 80 \\
\hline
\end{tabular}




\begin{tabular}{|c|c|c|c|c|c|c|c|c|c|c|}
\hline 19. & $\mathrm{MH}$ & 20 & 9 & 8 & 18 & 8 & 13 & 76 & 100 & 76 \\
\hline 20. & MAL & 20 & 10 & 7 & 20 & 6 & 7 & 70 & 100 & 70 \\
\hline 21. & MEL & 20 & 10 & 8 & 14 & 8 & 12 & 72 & 100 & 72 \\
\hline 22. & MMF & 20 & 11 & 9 & 25 & 7 & 9 & 81 & 100 & 81 \\
\hline 23. & $\begin{array}{c}\text { MNR } \\
\text { O }\end{array}$ & 20 & 12 & 8 & 23 & 8 & 9 & 80 & 100 & 80 \\
\hline 24. & MYD & 20 & 13 & 7 & 23 & 9 & 8 & 80 & 100 & 80 \\
\hline 25. & MD & 20 & 10 & 7 & 20 & 7 & 6 & 70 & 100 & 70 \\
\hline 26. & MGD & 20 & 8 & 7 & 20 & 8 & 7 & 70 & 100 & 70 \\
\hline 27. & $\mathrm{MH}$ & 20 & 13 & 8 & 23 & 8 & 8 & 80 & 100 & 80 \\
\hline 28. & OMS & 20 & 12 & 7 & 23 & 8 & 10 & 80 & 100 & 80 \\
\hline 29. & $\mathrm{AE}$ & 20 & 12 & 8 & 21 & 7 & 13 & 81 & 100 & 81 \\
\hline 30. & $\mathrm{OK}$ & 20 & 7 & 8 & 18 & 7 & 10 & 70 & 100 & 70 \\
\hline 31. & SD & 20 & 10 & 7 & 13 & 6 & 11 & 70 & 100 & 70 \\
\hline 32. & SFJ & 20 & 12 & 7 & 23 & 8 & 10 & 80 & 100 & 80 \\
\hline 33. & SES & 20 & 12 & 8 & 23 & 7 & 10 & 80 & 100 & 80 \\
\hline 34. & SA & 20 & 10 & 7 & 23 & 8 & 12 & 80 & 100 & 80 \\
\hline 35. & SAY & 20 & 13 & 8 & 20 & 9 & 12 & 81 & 100 & 81 \\
\hline 36. & SRG & 20 & 12 & 8 & 23 & 7 & 10 & 80 & 100 & 80 \\
\hline 37. & YF & 20 & 10 & 8 & 14 & 8 & 12 & 72 & 100 & 72 \\
\hline 38. & YEP & 20 & 10 & 7 & 23 & 8 & 12 & 80 & 100 & 80 \\
\hline 39. & YFA & 20 & 12 & 8 & 23 & 7 & 10 & 80 & 100 & 80 \\
\hline 40. & $\mathrm{YD}$ & 20 & 10 & 8 & 18 & 7 & 7 & 70 & 100 & 70 \\
\hline & $\underset{\underline{\Xi}}{\frac{\underline{\pi}}{\mathbb{Z}}}$ & 800 & 456 & 298 & 836 & 307 & 403 & 3099 & 4000 & 3099 \\
\hline & 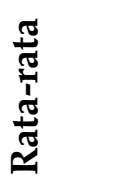 & 20 & 11,4 & 7,45 & 20,9 & 7,67 & 10,075 & 77,47 & $100 \%$ & 77,47 \\
\hline
\end{tabular}

Hasil kerja siswa menunjukan semua siswa 40 siswa sampel untuk menentukan tema dengan jumlah 800 dengan rata-rata 20 judul dengan jumlah 456 dengan rata-rata 11,4 amanat dengan jumlah 298 dengan rata-rata 7,45 diksi jumlah 836 dengan rata-rata 20,9rima dengan jumlah 307 dengan rata-rata 7,67 dan majas dengan jumlah 403 dan ratarata 10,075 .

\section{Hasil dan Pembahasan}

Berdasarkan penjelasan pada metode penelitian di atas, pada bagian deskripsi hasil penelitian menunjukan bahwa kemampuan siswa dalam menulis puisi bebas tentang keindahan alam melalui metode tes tergolong baik. Hal ini dapat dilihat melalui data yang ditabulasi, pada tabel (4) yaitu tabel tes belajar dengan nilai yang diperoleh berkisar antara 
70 sampai 81. Berdasarkan data pada tabel ke (2) ini, diperoleh presentasenya $77,47 \%$. Melalui data presentasenya dapat dikatakan bahwa penguasaan siswa terhadap kemampuan menulis puisi tentang keindahan alam dengan menggunakan media gambar tergolong baik.

Berdasarkan data yang disajikan pada tabel (4) menggambarkan bahwa siswa kelas VII SMPK Santo Aloysius Lengko Ajang Manggarai Timur Tahun Ajaran 2017/2018 memiliki kemampuanmenulis puisi tentang keindahan alam tergolong cukup baik dengan presentase $77,47 \%$. Melalui analisis data tersebut maka dapat dikatakan pembelajaran dengan menggunakan metode tes dan menggunakan media gambar berhasil.

Berdasarkan pengalaman sebelumnya metode yang digunakan dalam pembelajaran mengapresiasikan puisi di sekolah berupa metode tes tertulis dan hasilnya belum berhasil. Dengan menggunakan media gambar siswa lebih aktif dan kreatif untuk berpikir. Disamping itu melalui media ini memungkinkan konsep sehingga anak lebih terbuka pada pengalaman-pengalaman nyatanya dan lebih bersifat deskriptif. Penggunaan media gambar juga sangat membantu siswa dalam proses belajar. Media gambar sangat terbantu bagi siswa terlebih khusus dalam menulis puisi, daya imajinasi siswa sangat cepat dan terinspirasi dan lebih kreatif. Jadi dengan menggunakan media gambar ini dalam pembelajaran menulis puisi tentang keindahan alam, sangat menguntungkan bagi siswa karena siswa mampu menemukan sendiri kesulitan dan berusaha peran aktif dalam pembelajaran yang sedang berlangsung.

Setelah memperoleh data dan menganalisis data melalui metode statistik tentang kemampuan siswa dalam menulis puisi dengan menggunakan media gambar, dengan tema keindahan alam pada siswa SMPK Santo Alysius Lengko Ajang Manggarai Timur, maka dapat diuraikan sebgai berikut:

a. Tingkat kemampuan siswa kelas VII SMPK Santo Aloysius Lengko Ajang Kecamatan Sambi Rampas Kabupaten Manggarai Timur terhadap materi menulis puisi tentang keindahan alam dengan menggunakan media gambar tergolong berhasil.

b. Presentase terakhir yang mencapai $77,47 \%$ menggambarkan keberhasilan siswa pada materi pelajaran menulis puisi tentang keindahan alam. Penggunaan media gambar ini tidak terlepas dari peran guru sebagai fasilitator dalam mengimplementasikan materi pembelajaran.

c. Siswa yang berhasil mencapai ketuntasan berjumlah 31 orang sedangkan siswa yang tidak tuntas berjumlah 9 orang.

d. Keberhasilan yang diperoleh tentunya barasal dari respon siswa yang tinggi dalam mengikuti pembelajaran di sekolah.

e. Pemilihan media pembelajaran juga sesuai dengan rencana pelaksanaan pembelajaran sehingga terarah, tidak membingungkan siswa.

Dari 40 orang siswa yang tuntas sesuai KKM sebanyak 31 orang siswa dengan presentase $77,5 \%$. Sedangkan yang tidak tuntas berjumlah 9 orang dengan presentase $22,5 \%$.

\section{Kesimpulan}

Kemampuan menulis puisi dengan menggunakan media gambar pada siswa SMPK Santo Aloysius Lengko Ajang kelas VII secara keseluruhan tergolong baik dengan rata-rata pencapaian $77,47 \%$. Siswa yang tuntas berjumlah 31 orang dengan presentase $77,5 \%$. Sedangkan siswa yang tidak tuntas bejumlah 9 orang dengan presentse $22,5 \%$. Penggunaan media gambar pada penulisan puisi mempunyai pengaruh yang sangat baik 
bagi keterampilan siswa dalam menulis. Antusias, kreativitas, dan imajinasi siswa dapat terlihat pada proses pembelajaran di dalam kelas. Saran kepada pihak yang mempunyai kaitan langsung maupun tidak langsung dalam kegiatan pembelajaran ini.

\section{Daftar Pustaka}

Abidin, Y.Z. (2015). Metode Penelitian Komunikasi Penelitian Kuantitatif: Teori dan Aplikasi. Bandung: Pustaka Setia.

Burhan, B. (2005). Metodologi Penelitian Kuantitatif: Komunikasi, Ekonomi, dan Kebijakan Publik Serta Ilmu-Ilmu Sosial Lainnya, Jakarta: Kencana.

Hanafiah., \& Suhana. (2010). Konsep Strategi Pembelajaran. Bandung. Refika Aditama.

Iskandar, D., \& Narsim. (2015). Penelitian Tindakan Kelas dan Publikasinya Untuk Kenaikan Pangkat dan Golongan Guru E Pedoman Penulisan PTK bagi Mahasiswa.Cilacap:Ihya Media.

Prihatin, E. (2008). Guru Sebagai Fasilitator. Bandung. Karsa Mandiri Persada

Puskur. (2006). Kurikulum Tingkat Satuan Pendidikan. Jakarta: Depdiknas.

Ridwan., \& Akdon. (2013). Rumus dan Data dalam Analisis Statistika. Bandung: Alfabeta.

Sanjaya, W. (2006). Strategi Pembelajaran Berorientasi Standar Proses Pendidikan. Jakarta: Kencana Prenada Media Group.

Sugiyono. (2017). Metode Penelitian Kuantitatif, Kualitatif, dan RED. Bandung: Alfabeta,CV

Uer, T.U.K. (2013). Sosiologi Sastra. Ende: Nusa Indah.

Wissang. (2014). Memahami Puisi dari Apresiasi Menuju Kajian. Yogyakarta: Penerbit Ombak. 